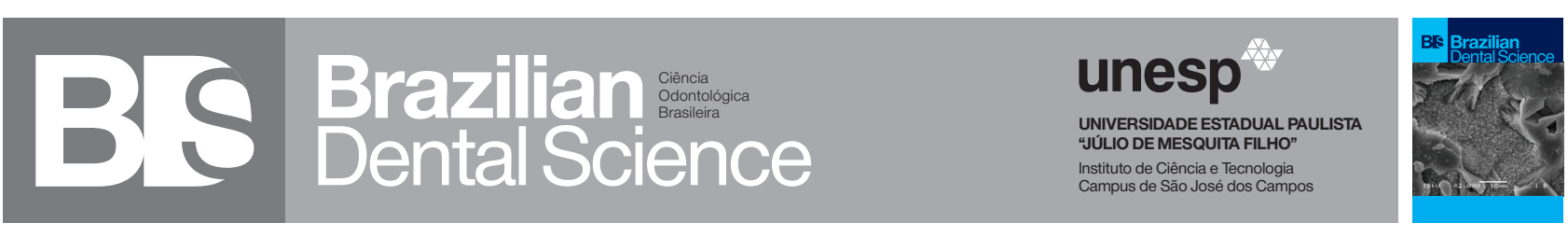

\title{
Relationship of Oral Aesthetic Assessment according to Self Perception with Oral Malocclusion Condition of High School Students in Sidrap District, South Sulawesi Indonesia
}

Relação da avaliação estética de acordo com a autopercepção da condição de má oclusão oral de estudantes do ensino médio no distrito de Sidrap, Sulawesi do Sul na Indonésia

Burhanuddin Daeng PASIGA ${ }^{1}$, Rasmidar SAMAD ${ }^{1}$, Rini PRATIWI ${ }^{1}$

1 - Department of Dental Public Health - Faculty of Dentistry - Hasanuddin University - Makassar - Indonesia.

\begin{abstract}
Self-perception of dental aesthetics needs to be considered in planning orthodontic treatment because it is known that everyone has a self-perception of different oral esthetic conditions. Objective: To assess the state of malocclusion based on self-perception of dental aesthetics using the Oral Aesthetic Subjective Impact Score (OASIS); to determine the relationship of self-perceptions of oral aesthetics and the state of malocclusion from the results of clinical examinations using the Dental Aesthetic Index (DAI). Material and Methods: Research subjects were middle school students aged between 14-18 years as many as 187 students. For oral aesthetic assessment using the OASIS index questionnaire, and to evaluate the aesthetic and anatomical components of the malocclusion clinic using the Dental Aesthetic Index (DAI). Results: The prevalence of malocclusion according to Dental Aesthetic Index (DAI) showed that mild / normal malocclusion (59.9\%), moderate malocclusion (33.4\%), severe malocclusion (5.7\%), and very severe malocclusion $(1 \%)$. The prevalence of self-perception of oral aesthetics was $54.6 \%$ judging good. The results of the analysis with logistic regression tests showed that there was a significant $(\mathrm{p}<0.001)$ relationship between self-perception of oral aesthetics using the OASIS index and malocclusion status using the DAI index. Conclusion: Based on the results of this study, there was a significant relationship ( $p<0.01)$ between oral aesthetic self perception and malocclusion status of high school students.
\end{abstract}

\section{KEYWORDS}

Oral aesthetic perception; Oral aesthetic subjective impact score; Dental aesthetic index.

\section{RESUMO}

A autopercepção da estética dentária precisa ser considerada no planejamento do tratamento ortodôntico, porque é sabido que existem diferenças nesta autopercepção de condições estéticas orais entre os indivíduos. Objetivo: Avaliar o estado de má oclusão com base na autopercepção da estética dentária utilizando o Oral Aesthetic Subjective Impact Score (OASIS); determinar a relação entre a autopercepção da estética bucal e o estado de má oclusão a partir dos resultados de exames clínicos utilizando o Índice de Dental Aesthetic Index (DAI). Material e Métodos: Os sujeitos da pesquisa foram estudantes do ensino médio, com idades entre 14 e 18 anos, num total de 187 alunos. Para avaliação da estética bucal, foi utilizado o questionário do índice OASIS, e para avaliar os componentes estéticos e anatômicos da clínica de más oclusões, o Índice de DAI. Resultados: A prevalência de má oclusão segundo o DAI, mostrou resultados de percepção de: oclusão leve / normal (59,9\%), oclusão moderada $(33,4 \%)$, oclusão grave $(5,7 \%)$ e oclusão muito grave $(1 \%)$. A prevalência de autopercepção da estética oral foi de 54,6\%, considerando-se boa. Os resultados da análise com testes de regressão logística mostraram que houve uma relação significativa ( $p$ $<0,001$ ) entre a autopercepção da estética oral usando o índice OASIS e o status de má oclusão usando o índice DAI. Conclusão: Com base nos resultados deste estudo, houve uma relação significativa ( $p<0,01$ ) entre a autopercepção da estética oral e o estado de má oclusão de estudantes do ensino médio.

\section{PALAVRAS-CHAVE}

Percepção estética oral; Escore de impacto subjetivo estético oral; Índice de estética dental. 


\section{INTRODUCTION}

$\mathrm{P}$ erson's appearance can be influenced by oral aesthetics, so lately the development of the world of cosmetic dentistry has become advanced because of the increased attention and public awareness of beautiful and attractive facial appearance especially for young women as a trend in modern life [1]. The appearance of the face by malocclusion teeth can affect psychological factors, social factors, and the quality of life of patients. The clinical consequences of dental conditions and the self-perception of oral aesthetics can determine the decision to do dental treatment, especially orthodontic treatment [2].

The World Health Organization (WHO) defines the adolescence period as a period of growth and development that occurs after the childhood period and before the adult period begins, from the age of 10-19 years [3]. Ages 16-17 years are the age of puberty who experience physical changes. This age generally experiences a lot of dissatisfaction with their own physical condition which is not in accordance with their expectations or perceptions of ideal physical conditions, including their oral aesthetic conditions [4].

The appearance of the face is inseparable from the context of beauty and good looks, a beautiful and handsome face certainly has an ideal proportion and an attractive smile. To get an attractive smile there are many factors that play a role such as lips, gingiva, and teeth $[5,6]$. Teeth with a neat arrangement and a charming smile will have a positive effect, otherwise irregular teeth will give a negative suggestion to someone so will cause adverse effects in social interactions [7].

The irregularity of the tooth arrangement causes malocclusion and is the most common dental problem in humans. Although malocclusion that occurs in a person is not life threatening but is considered an important problem regarding dental and oral health in the community. It is known that malocclusion includes oral tissue health and can also cause psychological and social problems. Malocclusion can also damage facial aesthetics, difficulty in mastication, swallowing, speaking, and also affect quality of life [2].

According to Shaw's research on the relationship of malocclusion with social effects in adolescents shows that malocclusion causes high problems in social relationships [8]. Malocclusion also greatly influences adolescent perceptions of facial aesthetics which causes adolescents not to be confident and feel inferior in interacting socially with their peers [9].

Perception is a process of selecting, regulating and interpreting various sensory information received to obtain an understanding. A person's perception of the aesthetics of his teeth varies. Some teenagers feel dissatisfied with the condition of their teeth, even though the dental irregularities they have are minimal, but others do not care about the malocclusion they experience because basically, they feel comfortable with their aesthetic state [10].

There are differing perceptions in aesthetic assessments in adolescents which then encourage Mandall to publish an index known as the Oral Aesthetic Subjective Impact Score (OASIS) [11,12]. OASIS is a relatively new independent self-evaluation tool that has been used to measure perceptive care needs. This is consumer-based action based on the socio-psychological impact that children feel from their malocclusion. Self-perception of oral aesthetics can determine orthodontic treatment needs. OASIS has been developed to evaluate dental aesthetics based on selfassessment by filling out questionnaires. OASIS can also know how dental deviations can affect 
the quality of life and social relationships for those suffering from malocclusion $[13,14]$.

Another index that is also often used to measure the level of orthodontic treatment needs, namely Dental Aesthetic Index (DAI) 15. The DAI index includes a component of clinical assessment and assesses the functional and aesthetic aspects of the dental condition and can indicate the severity of malocclusion and can determine the level of orthodontic treatment needs. The DAI index is often and easy to use and does not require a lot of time [15].

The purpose of the study was to determine the relationship between selfperception of oral aesthetics and malocclusion status for high school students in Sidendeng Rapang District. South Sulawesi, Indonesia.

\section{MATERIALS AND METHOD}

\section{Study design}

This type of research is an observational study and a cross-sectional study design. A total of 184 samples were taken from all high school students of class X-XII, Department of Natural Sciences from High School Students in Sidrap Regency. South Sulawesi. The study was approved by the Ethics Commission of the Faculty of Dentistry of UNHAS and there was permission to implement the School.

\section{Operational definition}

1. Self-perception about oral aesthetics is a process for assessing the appearance of a face or teeth that is judged by oneself using the OASIS questionnaire.

2. Dental Aesthetic Index (DAI) is an index used to measure the severity of malocclusion and evaluate the aesthetic component of the tooth.

\section{Assessment criteria}

1. Self-perception of oral aesthetics

Oral aesthetic self perception was measured using a questionnaire from "Oral Esthetic Aesthetic Score (OASIS)" which consisted of several questions that assessed attention levels and lost tooth appearance. Research subjects were asked to choose one option by checking the questionnaire from 7 choices from the Likert scale (Table 1).

OASIS scale information can be divided into 3 groups, namely scale 1, 2, 3 shows no matter / never, scale 4 shows neutral, scale 5 , 6, 7 shows care / ever. OASIS score results are grouped based on good self-perception and poor self-perception.

Good self-perception: Total score 5-16

Poor self-perception: Total score 17 - 35

2. State of oral malocclusion/aesthetics

To determine the condition of malocclusion using DAI (Dental Aesthetic Index) by filling in the existing components in the sheet from the results of clinical examination (Table 2).

The score results of each case were grouped according to the severity of malocclusion. The group of malocclusions based on the DAI score was $<25$ as normal occlusion / mild malocclusion; the value of 26-30 is as moderate malocclusion; values 3135 as moderate malocclusion; values $31-35$ as severe malocclusion and values $>36$ as very malocclusion. 
Table 1 - Distributions of OASIS components

\begin{tabular}{|c|c|c|c|c|c|c|}
\hline \multicolumn{7}{|c|}{ Question 1: How do you feel about the appearance of your teeth? } \\
\hline 1 & 2 & 3 & 4 & 5 & 6 & 7 \\
\hline do not care at all & & & & & & Very care \\
\hline \multicolumn{7}{|c|}{ Question 2: Have you found that other people have commented on the appearance of your teeth } \\
\hline 1 & 2 & 3 & 4 & 5 & 6 & 7 \\
\hline \multicolumn{7}{|c|}{ Question 3: Do you try to avoid smiling because of the appearance of your teeth? } \\
\hline 1 & 2 & 3 & 4 & 5 & 6 & 7 \\
\hline \multicolumn{7}{|c|}{ Question 4: Apakah Anda menghindari tersenyum karena penampilan gigi Anda? } \\
\hline 1 & 2 & 3 & 4 & 5 & 6 & 7 \\
\hline \multicolumn{7}{|c|}{ Question 5: Do you ever cover your mouth because of the appearance of your teeth? } \\
\hline 1 & 2 & 3 & 4 & 5 & 6 & 7 \\
\hline
\end{tabular}

${ }^{*}$ Scores 1 to 7 represent a seven-point Likert scale, where the score 1 indicates the best perception of dental appearance and score 7 indicates the poorest.

Table 2 - DAI Score Standards

\begin{tabular}{|c|c|c|c|c|}
\hline No. & DAIComponent & $\begin{array}{l}\text { regresion } \\
\text { coeficient }\end{array}$ & $\begin{array}{l}\text { Value } \\
\text { examination }\end{array}$ & $\begin{array}{l}\text { (regresion coeficient) } x \\
\text { value examination }\end{array}$ \\
\hline 1 & $\begin{array}{l}\text { DAI Components Number of missing visible teeth (incisors, Cani- } \\
\text { nes and premolars teeth in the maxillary and mandibular arches) }\end{array}$ & 6 & & \\
\hline 2 & $\begin{array}{l}\text { Crowding in the incisal segments: }(0=\text { no segment crowded, } 10 \\
\text { one segments crowded, } 2=\text { two segment crowded })\end{array}$ & 1 & & \\
\hline 3 & $\begin{array}{l}\text { Spacing in the incisal segments: }(0=\text { no spacing, } 1=\text { one segment } \\
\text { spaced, } 2 \text { = two segment spaced) }\end{array}$ & 1 & & \\
\hline 4 & Midline diastema, in millimeters & 3 & & \\
\hline 5 & Largest anterior maxillary irregularity, in millimeters Largest & 1 & & \\
\hline 6 & Largest anterior mandibular irregularity, in millimeters & 1 & & \\
\hline 7 & Anterior maxillary overjet, in millimeters Anterior & 2 & & \\
\hline 8 & Anterior mandibular overjet, in millimeters Vertical & 4 & & \\
\hline 9 & Vertical anterior open bite, in millimeters & 4 & & \\
\hline 10 & $\begin{array}{l}\text { Anteroposterior molar relationship, largest deviation from normal } \\
\text { either left or right: }(0=\text { normal, } 1=1 / 2 \text { cusp either mesial or } \\
\text { distal, } 2=\text { one full cusp or more either mesial or distal) }\end{array}$ & 3 & & \\
\hline \multirow[t]{2}{*}{11} & Constan & 13 & 13 & 13 \\
\hline & Total & \multicolumn{2}{|c|}{ Score DAI } & \\
\hline
\end{tabular}




\section{Data Analysis}

Data analysis using descriptive analysis and to determine the relationship of oral aesthetic assessments between the OASIS index and assessment with DAI using the Logistic regresion test with using the SPSS 24.0 program.

\section{Result}

Table 3 shows descriptively from 187 students with an average age $=16.82$ years. According to sex, female (60.4\%), male (39.6\%). According to the location of residence obtained for urban areas $(26.2 \%)$ and rural areas $(73.8 \%)$.

Figure 1 shows the prevalence of malocclusion based on Dental Aesthetic Index (DAI) with 59.9\% with mild/normal malocclusion, $33.4 \%$ with moderate malocclusion, $5.7 \%$ with severe malocclusion, and $1 \%$ with very severe malocclusion.

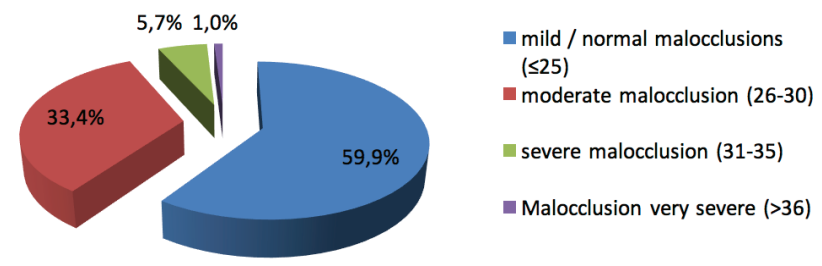

Figure 1 - Prevalence of malocclusion based on Dental Aesthetic Index (DAI).

Table 3 - Distribution of the study population based on sociodemographic factors

\begin{tabular}{|c|c|c|c|c|}
\hline \multicolumn{2}{|c|}{ Characteristics } & \multirow{2}{*}{$\begin{array}{l}n \\
4\end{array}$} & \multirow{2}{*}{$\begin{array}{l}\% \\
2.1\end{array}$} & \multirow{2}{*}{ Mean $\pm s d$} \\
\hline \multirow{5}{*}{ Age } & 14 years & & & \\
\hline & 15 years & 44 & 23.5 & \multirow{4}{*}{$16.2 \pm 0.89$} \\
\hline & 16 years & 73 & 29.0 & \\
\hline & 17 years & 58 & 31.0 & \\
\hline & 18 years & 8 & 4.3 & \\
\hline \multirow{2}{*}{ Sex } & Male & 74 & 39.6 & \\
\hline & Female & 113 & 60.4 & \\
\hline \multirow{2}{*}{ Location } & Urban & 49 & 26.2 & \\
\hline & Rural & 138 & 73.8 & \\
\hline
\end{tabular}

Table 4 shows the distribution of the percentage of sample answers based on selfperception of oral aesthetics ( $\mathrm{n}=187$ samples). In the first question, the most answers are caring for the appearance of 108 people (58.28\%), taking for granted 43 people (23.0\%) and not caring about the state of their teeth as many as 35 people (18.72\%). In the second question, the majority answered never as many as 106 people $(56.7 \%)$, neutral as many as 30 people (16\%), and never as many as 51 people (27.3\%). In the third question, the most answers are never 129 people (69\%), neutral 22 people (11.8\%), and never 36 people (19.3\%). In the fourth question, the majority never answered as many as 132 people (70.6\%), neutral as many as 37 people (19.8\%), and as many as 21 people (11.2\%). On the fifth question, most of the answers did not care / never 125 people $(66.8 \%)$, were neutral and never had as many as 31 people $(16.6 \%)$.

Table 4 - Distribution of research subjects based on OASIS scores

\begin{tabular}{|c|c|c|c|c|c|c|c|c|}
\hline \multicolumn{9}{|c|}{ Likert Scale } \\
\hline \multirow{2}{*}{ Question } & \multicolumn{2}{|c|}{ Don't Care } & \multicolumn{2}{|c|}{ Neutral } & \multicolumn{2}{|c|}{ Care } & \multirow[b]{2}{*}{$\begin{array}{c}7 \\
\mathrm{n}(\%)\end{array}$} & \multirow{2}{*}{$\begin{array}{c}\text { Mean } \pm \\
\text { sd }\end{array}$} \\
\hline & $\begin{array}{c}1 \\
n(\%)\end{array}$ & $\stackrel{2}{n(\%)}$ & $\begin{array}{c}3 \\
n(\%)\end{array}$ & $\begin{array}{c}4 \\
n(\%)\end{array}$ & $\begin{array}{c}5 \\
n(\%)\end{array}$ & $\begin{array}{c}6 \\
n(\%)\end{array}$ & & \\
\hline \multirow[t]{2}{*}{$\begin{array}{l}\text { Q1. How do you } \\
\text { feel about the } \\
\text { appearance of } \\
\text { your teeth? }\end{array}$} & $\begin{array}{c}5 \\
(2.7)\end{array}$ & $\begin{array}{c}11 \\
(5.91)\end{array}$ & $\begin{array}{c}19 \\
(10.2)\end{array}$ & $\begin{array}{c}43 \\
(22.1)\end{array}$ & $\begin{array}{c}34 \\
(18.2)\end{array}$ & $\begin{array}{c}41 \\
\text { (21.9) }\end{array}$ & $\begin{array}{c}34 \\
(18.2)\end{array}$ & $4.87 \pm 1.59$ \\
\hline & & Never & & leutral & & Ever & & \\
\hline $\begin{array}{l}\text { Q2. Have you } \\
\text { found that other } \\
\text { people have } \\
\text { commented on } \\
\text { the appearance } \\
\text { of your teeth? }\end{array}$ & $\begin{array}{c}14 \\
(7.5)\end{array}$ & $\begin{array}{c}42 \\
(22.4)\end{array}$ & $\begin{array}{c}52 \\
(27.8)\end{array}$ & $\begin{array}{c}30 \\
(16.0)\end{array}$ & $\begin{array}{c}33 \\
(17.6)\end{array}$ & $\begin{array}{c}16 \\
(8.5)\end{array}$ & $\begin{array}{c}0 \\
(0)\end{array}$ & $3.40 \pm 1.42$ \\
\hline $\begin{array}{l}\text { Q3. Have you } \\
\text { found that other } \\
\text { people have } \\
\text { teased you about } \\
\text { the appearance } \\
\text { of your teeth? }\end{array}$ & $\begin{array}{c}27 \\
(14.4)\end{array}$ & $\begin{array}{c}58 \\
(31.0)\end{array}$ & $\begin{array}{c}47 \\
(25.1)\end{array}$ & $\begin{array}{c}22 \\
(11.8)\end{array}$ & $\begin{array}{c}29 \\
(15.5)\end{array}$ & $\begin{array}{c}4 \\
(24)\end{array}$ & $\begin{array}{c}0 \\
(0)\end{array}$ & $2.90 \pm 1.35$ \\
\hline $\begin{array}{l}\text { Q4. Do you try } \\
\text { to avoid smiling } \\
\text { because of the } \\
\text { appearance of } \\
\text { your teeth? }\end{array}$ & $\begin{array}{c}43 \\
(22.1)\end{array}$ & $\begin{array}{c}60 \\
(321)\end{array}$ & $\begin{array}{c}31 \\
(16.6)\end{array}$ & $\begin{array}{c}36 \\
(19.2)\end{array}$ & $\begin{array}{c}7 \\
(3.7)\end{array}$ & $\begin{array}{c}11 \\
(5.9)\end{array}$ & $\begin{array}{c}2 \\
\text { (1.1) }\end{array}$ & $2.70 \pm 1.48$ \\
\hline $\begin{array}{l}\text { Q5. Do you ever } \\
\text { cover your mou- } \\
\text { th because of the } \\
\text { appearance of } \\
\text { your teeth? }\end{array}$ & $\begin{array}{c}34 \\
(18.2)\end{array}$ & $\begin{array}{c}63 \\
(33.7)\end{array}$ & $\begin{array}{c}30 \\
(16.0)\end{array}$ & $\begin{array}{c}30 \\
(16.0)\end{array}$ & $\begin{array}{c}18 \\
(9.6)\end{array}$ & $\begin{array}{c}10 \\
(5.3)\end{array}$ & $\begin{array}{c}2 \\
(1.1)\end{array}$ & $2.86 \pm 1.50$ \\
\hline $\mathrm{Q}=$ Question & & & & & & & & \\
\hline
\end{tabular}


Table 5 shows the distribution of research subjects based on self-perception. There were 102 people $(54.6 \%)$ who had good selfperceptions of their original aesthetics. There were 85 people $(45.5 \%)$ who had a bad selfperception of their original aesthetics.

Table 5 - Distribution of research subjects based on selfperception

\begin{tabular}{|c|ccc|}
\hline & Variable & n & $\%$ \\
\hline \multirow{2}{*}{ OASIS } & Better self perception & 102 & $54,60 \%$ \\
\hline & Poorer Self perception & 85 & $45,50 \%$ \\
\hline
\end{tabular}

Table 6 shows that for DAI assessment, clinical data for the normal occlusion group had OASIS with a good perception of $82.1 \%$ and a poor rating of $17.8 \%$. Whereas the DAI assessment group with moderate malocclusion had a poor perception of OASIS (84.4\%). Statistical analysis test results there is a very significant relationship between assessments based on clinical conditions using DAI with self-perception of oral esthetics ( $p<0.001)$.

Table 6 - Association between OASIS and oral clinical data

\begin{tabular}{|c|c|c|c|c|}
\hline \multirow{2}{*}{\multicolumn{2}{|c|}{ Clinical Data }} & \multicolumn{2}{|c|}{ OASIS } & \multirow[b]{2}{*}{ p } \\
\hline & & $\begin{array}{l}\text { Better self } \\
\text { perception }\end{array}$ & $\begin{array}{l}\text { Poorer self } \\
\text { perception }\end{array}$ & \\
\hline \multirow{4}{*}{ DAI } & $\begin{array}{l}\text { Normal / mild } \\
\text { malocclusion }\end{array}$ & $92(82.1 \%)$ & $20(17.8 \%)$ & \multirow{4}{*}{0.0001} \\
\hline & $\begin{array}{l}\text { Moderate } \\
\text { malocclusion }\end{array}$ & $10(15.6 \%)$ & $54(84.4 \%)$ & \\
\hline & $\begin{array}{l}\text { Severe maloc- } \\
\text { clusion }\end{array}$ & 0 & $11(100)$ & \\
\hline & $\begin{array}{c}\text { Maloklusi } \\
\text { sangat parah }\end{array}$ & 0 & $2(100)$ & \\
\hline
\end{tabular}

a. 2 cells $(25.0 \%)$ have expected count less than 5 . The minimum expected count is .91 .
Table 7 - Association between OASIS and oral clinical data

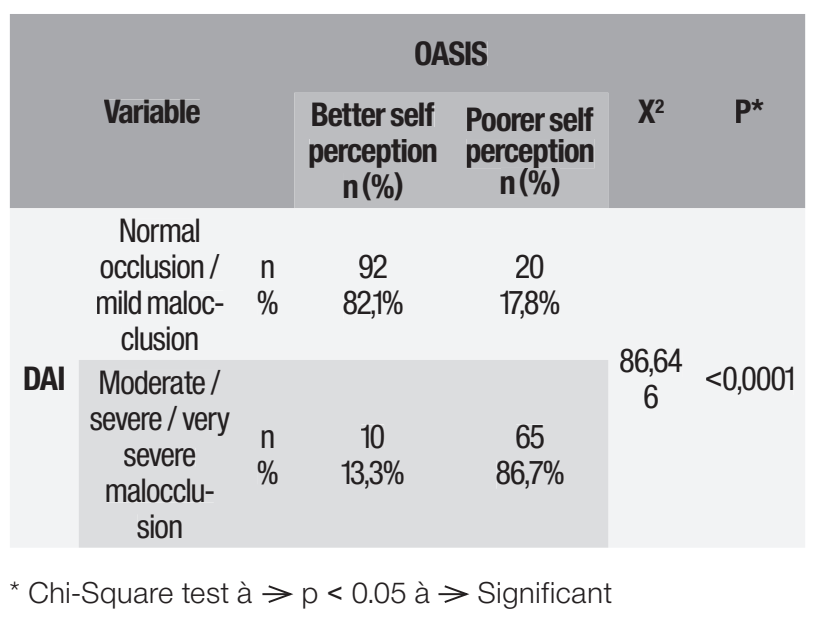

Table 8 shows that the group with moderate / severe / very severe malocclusion had 31 times a bad perception of themselves compared to those who experienced mild or normal malocclusion.

Table 8 - Logistic regression results indicating associations between poorer OASIS and oral clinical conditions

\begin{tabular}{|c|c|c|c|c|}
\hline & Variable & OR & $95 \% \mathrm{Cl}$ & $P^{*}$ \\
\hline \multirow[b]{2}{*}{ DAI } & $\begin{array}{l}\text { Normal occlusion / mild } \\
\text { malocclusion }\end{array}$ & 1.00 & \multirow[b]{2}{*}{$\begin{array}{c}13.852- \\
71.585\end{array}$} & \multirow[b]{2}{*}{$<0,001$} \\
\hline & $\begin{array}{c}\text { Moderate / severe / very } \\
\text { severe } \\
\text { malocclusion }\end{array}$ & 31.490 & & \\
\hline
\end{tabular}

\section{DISCUSSION}

The assessment of aesthetic perceptions in each person is different because the assessment is subjective. Some researchers standardize perceptual values so that they can be assessed. In this study, using the OASIS index that assessed $1 / 3$ of the lower face area and was usually associated with teeth and smiled when smiling ${ }^{10}$. This index provides 5 questions that make it easier for teens to determine the answer using the Likert scale as a measuring instrument. 
In this study, people who experienced malocclusion based on DAI scores were $40.5 \%$ at. A higher DAI score was observed in a previous study conducted by Uthaman C, which was $41.8 \%{ }^{13.15}$ A relatively low DAI score was observed in the study Tak $\mathrm{M}^{16}$, namely $33.3 \%$, respectively. Variations in DAI scores may be related to different cross-cultural differences, the development of the facial skeleton, occlusion and genetic predisposition. Mandall proposed an instrument for assessing perceptions of oral aesthetics and how dental irregularities interfere with their lives and social relationships negatively ${ }^{10}$. The results of this study indicate that individuals with moderate, severe, very severe malocclusion have worse self-perception of oral aesthetics. The results are in accordance with previous research conducted by Claudino $\mathrm{D}^{17}$. It can be explained that individuals with severe malocclusion have a poor self-perception of oral aesthetics. The results of this study differ from other studies where there was no significant relationship between malocclusion and selfperception of oral aesthetics ${ }^{18}$, but unlike the research conducted by Gupta R, women were more significant because inheritance in this age group cared more about their aesthetics ${ }^{12}$.

Logistic regression analysis showed a statistical relationship between self-perception and oral aesthetics. Individuals with severe malocclusion have a worse self-aesthetic perception when compared to individuals with mild malocclusion. This result is also supported by Hamamci's research which concluded that subjects suffering from severe or very severe malocclusion statistically affected the satisfaction of their teeth appearance ${ }^{10,19}$. The results of the analysis with logistic regression showed that there was an influence between selfperceptions of oral aesthetics Individuals with severe malocclusion had a worse perception of self aesthetics when compared to individuals with mild malocclusion. This result was also supported by Hamamci's research which concluded that subjects who suffered from severe or very severe malocclusion statistically affected the satisfaction of the appearance of their teeth. Malocclusion disorders, especially anterior teeth can affect one's aesthetic perception, this is because the attractiveness of the face and teeth is an important element in the quality of one's life ${ }^{20}$. In this study it is important to keep in mind the limitations because there is no causal relationship between malocclusion and poor self perception of oral aesthetics. In addition, the use of the DAI index is only for permanent teeth, not for primary teeth and mixed teeth so that it cannot identify cases of malocclusion from the initial stage.

\section{CONCLUSION}

Based on the results of this study, there was a significant relationship ( $\mathrm{p}<0.01)$ between oral aesthetic self perception and malocclusion status of high school students.

\section{ACKNOWLEDGMENTS}

Acknowledgments to Sidendeng Rapang District Senior High School IV Head who gave permission to conduct this research and to students of the Hasanuddin University Dentistry who helped in this study.

\section{REFERENCES}

1. Major PW. Self-perceived orthodontic treatment need evaluated through 3 scales in a university population. 2004;31:329-334. doi:10.1179/146531204225020644.

2. Unit O.Perception of Orthodontic Treatment Need:Opinion Comparisons of Patients, Parents and Orthodontists. 2005;2:42-51.

3. Bourne CO,Balkaran R, ScottE. Orthodontic treatment needs in Caribbean dental clinics. Eur JOrthod.2012;34(4):525-530. doi:101093/ejo/cjr037.

4. Klages U,Bruckner A, Guld Y,Zentner A. Dental esthetics, orthodontic treatment, and oral-health attitudes in young adults. Am J Orthod Dentofac Orthop.2005;128(4):442-449. doi:10.1016/j.ajodo.2004.05.023.

5. Câmara CA. Estética em Ortodontia: seis linhas horizontais do sorriso. Dental Press JOrthod.2010;15(1):118-131. doi:10.1590/S2176-94512010000100014.

6. Sabri R. The eight components of a balanced smile. JClin Orthod. 2005. doi:10.1089/vbz.2008.0051.

7. FaMDe,Paula DFDe. Psychosocial Impact of Dental Esthetics on Quality of Life in Adolescents. doi:10.2319/082608-4521.

8. Shaw WC, Richmond S, Kenealy PM, Kingdon A, Worthington H. A20-year cohort study of health gain from orthodontic treatment: Psychological outcome. Am J Orthod Dentofac Orthop. 2007;132(2):146-157. doi:10.1016/j. ajod0.2007.04.009. 
9. Motloba D, Sethusa M, Ayo-Yusuf 0. The psychological impact of malocclusion on patients seeking orthodontic treatment ata South African oral health training centre. South African Dent J.2016;71(5):200-205.

10. Mandall NA, McCord JF, Blinkhorn AS, Worthington HV, O'Brien KD. Perceived aesthetic impact of malocclusion and oral self-perceptions in 14-15-yearold Asian and Caucasian children in greater Manchester. Eur J Orthod. 2000;22(2):175-183

11. Flores-Mir C,Major PW, Salazar FR. Self-perceived orthodontic treatment need evaluated through 3 scales in a university population. JOrthod. 2004;31(4):329334. doi:10:1179/146531204225020644.

12. Gupta R, Br C, GoelP,Saxena V, Ganavadiya R. Prevalence of malocclusion in relation to area of residence among 13-15 years old Government and Private school children in Bhopal district, Madhya Pradesh, India. Int JAdv Res. 2015;3(05):918-925.

13. Uthaman C,SequeiraS, Shamarao S. Perception of Personal Dental Appearance and Dental Aesthetic Index Score Among 18- to 20-year-old College Students in Rural South India. 2015;13(6):495-499. doi:10.3290/j.ohpd. a34374.

14. Jenny J, Cons KC. Establishing malocclusion severity levels on the Dental Aesthetic Index (DAl) scale. Aust Dent J.1996;41(1):43-46. doi:10.1111/j.1834-7819.1996.tb05654.x.
15. Padisar P,Naseh R, BabaKhani A, Jalayer S. Comparing Dental Aesthetic Index (DAI) and IOTN in Determining the Orthodontic Treatment Needs of Qazvin Students. Iran J Orthod.2016;11(2). doi:10.17795/ijo-6231.0riginal.

16. Tak M, Nagarajappa R, Sharda AJ, Asawa K, Tak A. Prevalence of malocclusion and orthodontic treatment needs among 12 - 15 years old school children of Udaipur, India. 2013;7:45-53. doi:10.4103/1305-7456.119071.

17. Claudino D, Traebert J.Malocclusion, dental aesthetic self-perception and quality of life in a 18 to 21 year-old population: A cross section study. BMC Oral Health.2013;13(1):1. doi:10.1186/1472-6831-13-3.

18. Prabhu S, Divya M, Kv S, Veena N. Journal of Oral Hygiene \& Prevalence of Malocclusion, Aesthetic Self-Perception and their Correlation among 18 to 24 Years Old College Students in Chennai. 2017;5(2):10-13. doi:10.4172/23320702.1000225 .

19. Article 0 . Psychosocial impact of dental aesthetics among sudanese high school students. 2016;19(2):32-39. doi:10.14295/bds.2016.v19i21225.

20. Khanehmasjedi M, Bassir L, Haghighizade MH. Evaluation of Orthodontic Treatment Needs Using the Dental Aesthetic Index in Iranian Students. 2013;15(10). doi:10.5812/ircmj.10536.

\section{Burhanuddin D. Pasiga}

\section{(Corresponding address)}

Department of Dental Public Health Faculty of Dentistry.

Universitas Hasanuddin. Makassar, Indonesia.

Date submitted: 2018 Dec 30

E-mail: bpasiga@unhas.ac.id / bpasiga@gmail.com 